\section{Parties discover technology}

\section{London}

WITH the whiff of a general election in the air, the two main British political parties have rushed to endorse a new recipe to boost technology transfer from academia to industry. In fact, their rapid response to what is only a draft report is a bit worrying to its author, Sir John Fairclough, for-

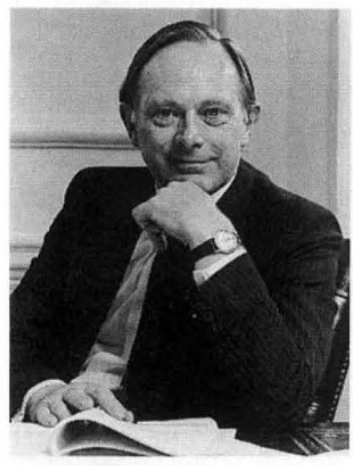

John Fairclough: worried merly chief scientific adviser to the UK government. And it could become a divisive issue for those research organizations that would be most affected if its suggestions were carried out.

Reports on technology

policy do not customarily receive such an instant political reaction. But then again, they are not usually released in the middle of a (still unofficial) general election campaign, when the political parties are keen to take on board any potentially votewinning initiative.

"It's rather nice to have both political parties supporting what you're doing," says Fairclough, chairman of the working party on innovation that wrote the report. "I just hope that it doesn't get screwed up."

The report argues that Britain needs a network of research institutes, doing contract work for industry, but closely associated with a university or polytechnic. These proposed 'Faraday Centres' are modelled loosely on the 35 German Fraunhofer Institutes - applied research centres with a total staff of almost 6,000 , including some 1,200 graduate students.

Fairclough's group, including many of Britain's leading science policy experts, was asked last year by the Prince of Wales to look at ways to bridge the gulf between British companies and universities. That gap is thought to be an important factor behind the common observation that many valuable technologies were invented in Britain, but exploited elsewhere.

Within hours of the report's release last week, the opposition Labour party issued its own technology plan, including an almost carbon-copy proposal for a series of 'Newton Institutes'. Labour science and technology spokesman Jeremy Bray says that his party's technology proposals are the result of two years of thought and consultation. But Bray conceded that the Newton Institute proposal is "remarkably similar" to the plan put forward by Fairclough's group.
The Conservative government, with the public purse at its disposal, was able to go one step further. The industry secretary, Peter Lilley, and Kenneth Clarke, his counterpart at the Department of Education and Science, announced a $£ 2$ million pilot programme to encourage five existing research organizations to take on up to 20 graduate students each in the coming year.

The document released by Fairclough's group last week was merely an interim report, and contains little detail about the number of graduate students who should be supported in the Faraday Centres, or how the programme would be funded. Fairclough says he would have preferred the government to wait until these details had been fully worked out before moving ahead with a pilot programme. The Centre for Exploitation of Science and Technology (CEST), a government- and industryfunded think-tank chaired by Fairclough, is now working on a more detailed plan.

Arguing that technology transfer is best achieved by the movement of people, Fairclough's group wants the best of Britain's existing independent research organizations to take on graduate students. The idea is that they would work towards their doctorates on industrially relevant research. Such training, so the theory goes, would make them more likely to move into industry than students in a traditional academic environment.

Last week's events may also force a change of plan at the Science and Engineering Research Council (SERC). The council, which funds more British graduate students than any other body, can expect to become closely involved with any Faraday Centre or Newton Institute initiative. SERC is working on a new graduate training scheme, leading to a doctorate, that is aimed specifically at young engineers.

The Fairclough group says that SERC's plan is complementary to its proposals. But SERC officials say they had planned to award these grants in the universities or polytechnics, and have not been consulted about the Faraday Centres idea.

There are already several dozen institutions in Britain that fit the mould of what is called for in the Fairclough report. John Bennett, secretary-general of the Association of Independent Research and Technology Organizations (AIRTO), whose 36 members mostly work on specialized contract research projects for industrial clients, says he is pleased that both political parties now recognize the need to strengthen the tier of research institutions between the universities and industry. "[Former prime minister Margaret] Thatcher believed you can bend academia and industry and get them to meet in the middle," he says. But that approach, Bennett believes, has not succeeded.

Nevertheless, the Faraday/Newton proposals would require companies that belong to AIRTO to become much more involved in training graduate students. Bob Whelan, chief executive of CEST, believes that up to 25 per cent of the staff of a Faraday Centre could be graduate students. But Bennett estimates that only about 50 of the 10,000 people that AIRTO members employ fit that description.

Many AIRTO members may also be reluctant to take on a large number of graduate students. Their fear is that academic influence may blunt their commercial edge. The Faraday/Newton proposals also imply the existence of a governmentlinked umbrella body to co-ordinate the scheme, which may put off some of the more fiercely independent of AIRTO's members.

Peter Aldhous

\section{EVOLUTION EDUCATION}

\section{Creationist victory}

California state education authorities last month agreed to pay $\$ 225,000$ to a creationist graduate school and to end any attempt to strip the school of its authority to grant masters degrees in science. In an out-of-court settlement, state lawyers agreed that the Institute for Creation Research (ICR) graduate school and other private, post-secondary educational institutions "may teach the creation model as being correct, provided the institution also teaches evolution."

"It's a shocking and puzzling decision", says Kevin Padian, a biologist at the University of California, Berkeley who lobbied against the ICR. "The state lawyers gave away the store." California is revising its education policies, he says, and state officials were unwilling to do battle with religious groups during this transition period.

Although the ICR legal challenge was based mostly on technicalities, the state lawyers agreed to a list of concessions that, among other things, would prevent Bill Honig, the state education superintendent, from participating in decisions about future ICR licences. Honig has ordered two scientific reviews that led to a recommendation to strip ICR of its degree-granting authority (see Nature 343, 501; 1990). Last month's settlement deletes those reports from the record.

Kenneth Cumming, dean of the ICR graduate school, hailed the settlement as a victory over Honig and other "notorious anti-creationists". The institute considers both evolution and creation to be theories, he says, although its instructors argue in favour of creationism. ICR grants about 25 masters degrees each year in biology, geology, astrogeophysics and science education.

Christopher Anderson 